\title{
Some Aspects of Oral Transmission in Japanese Tendai Buddhism
}

\section{Kwansei Tamura}

The term Kuden-hōmon (口傳法門) or the orally-transmitted-doctrine is, in a narrow sense, a general appellation of the unique doctrinal system fostered in Japanese Tendai Buddhism since the latter part of the Heian Period (A. D. 784-1185). In a broad sense, however, it can be applied to any kind of ancient religious literature which has been transmitted orally, as which is referred to by the term śruti or smrti in the Indian Vedic scriptures and Kataribé in Japanese mythology.

However, I shall use the term "orally-transmitted doctrine" here in its narrow sense, to refer to the particular doctrine of Tendai Buddhism.

Literally, Kuden (口傳) means oral transmission, i. e., the transmission of teachings, rites, practices, etc., by word of mouth from master to disciple. The primary meaning of Kuden was that these matters were not to be written down but were to be handed down face to face from master to disciple. However, Tendai Buddhism was traditionally proud of its doctrine expressing both the theoretical and practical aspects of Buddhism in strict conformity with the scriptures.

Until about a century after the death of Saichō (最澄) or Dengyō Daishi (傳教大師 767-822), founder of the Japanese Tendai Sect, it had been the attitude of orthodox Tendai followers to refer to the authority of scripture. Doctrinal positions independent of the intentions of the authorized scriptures had always been excluded as heretical.

Although some private oral tradition had existed from ancient times, it was only used to clarify the understanding of some versions of the scriptures and had never become the basis of any original doctrinal systems. 
At the time of Tao-sui (道遂 805-) and Hang-man (行滿 -824), both of whom were the disciples of Chan-jan (湛然 711-782), the sixth patriarch of Chinese T'ien-t'ai Sect, Saichō introduced Tendai Buddhism into Japan as a teaching distinct from its parent Chinese T’ien-T'ai Buddhism. In Japan, from the very beginning Saichō attempted to build up a great comprehensive Tendai Buddhism which was to unite the four schools: the Perfect Teaching (圓), which is the Tendai teaching proper, Zen (禪), Mahāyāna Precepts (戒) and Esoteric Doctrines (密). It must be noted that Japanese Tendai Buddhism began the harmonization of the Exoteric (顯㸚) and the Esoteric teachings. From the time of Saichō Japanese Tendai and Chinese T'ien-T'ai Buddhism are distinct traditions.

It was a great task, indeed, for Japanese Tendai Buddhism to embrace the Esoteric teaching, which was unknown to Chih-i (智顗 538-597), founder of the Chinese T'ien-T'ai Buddhism. It was also a great problem how to relate the newly embraced esoteric element to the hierarchy of the various tenets of Buddhism as defined by Tendai doctrine.

This effort of the Japanese Tendai School stimulated the development of this concept of Original Enlightenment (本覺思想) as a means for the solution of the problem. Thus the orthodox attitude of always asking for the justification of canonical authorities had to be changed. As the result, the concept of Original Enlightenment was justified in the name of oral transmission. Here for the first time we see the liberal interpretation of doctrine in contrast with adherence to canonical authorities. This trend strongly influenced the development of the mediæval Tendai doctrines in Japan.

\section{2}

After the prosperous age of Tendai Esoterism, from the time of Ennin (圓仁 791-862) to that of Annen (安然 841-897), Ryōgen (良源 912-985) devel. oped the Rongi (論義) a discussion technique, and restored the research activities of the Perfect teaching at Mt. Hiei. He completely renovated everything of the mountain-monastery. He was in fact an epoch-maker in the history of Japanese Tendai.

Genshin (源信 942-1017) of Eshin-in (慧心院) Temple and Kaku-un (覺運 
(42) Aspects of oral transmission in Japanese Tendai Buddhism(K. Tamura)

953-1007) of Danna-in (檀那院) Temple were his leading disciples and are regarded as the founders of the Eshin and Danna Schools, respectively. However, the founding neither of the Eshin nor of the Danna School is in fact to be connected with these two personalities, although theirs was the golden age of academic activity. This did not last long however. and was soon followed by dark times as the result of the antagonism and conflicts between the monks of Mt. Hiei and those of Mii-dera Temple and with the increasing fear and anxiety in the society as a result of the political struggles and the series of civil wars which characterized the late Heian Period.

Gradually, as the emphasis shifted from scriptural to oral traditions, arbitrary interpretations of doctrine without reference to the scriptures became rampant. Tendai scholars went so far as to fabricate some sūtras and commentaries, competing with each other by creating various mystic doctrines and rituals. It was they who are to be regarded as the real founders of the Eshin and Danna schools of the mediæval age. Why then did the follower of these schools look up to Genshin and Kaku-un as their founders and why did they call their schools after the names of Genshin's and Kaku-un's residential temples? Perhaps it is because they looked back to the golden age represented by Genshin and Kaku-un.

It must be noticed, however, that the doctrines orally-transmitted within the Eshin and Danna Schools were the predominant doctrines of mediæval Japanese Tendai and those which founded the background out of which developed the new sects of the Kamakura Period.

The secret doctrines, apparently having become fixed by the end of the Heian Period, were gradually committed to writing. Thus, the so-called records of oral transmission (口傳書) were made. The dates and authorship of all of

(1) The Kankōruijū (漢光類聚) ascribed to Chūjin (忠尋 1065-1138), states as follows: "These doctrines of oral transmission mentioned above have been kept in secret from the time of Dengyo Daishi (傳敉大師) until the sixth successor Kakuchō (覺超) at Tosotsu-in (鬼率院) temple without comittal to writing ". Cf. Taishō Tripițaka, Vol. 74, pp. 387c-388a. 
these documents are unknown or open to question.

The forged writings ascribed to the Three Sages and the Two Masters (三聖二師) of an earlier age should also be regarded as such products of the oral tradition. Their contents range from commentaries on the Three Great Works on the Lotus Sütra (法華三大部) and other works of Chih-i, to collections on items of catechism, oral decisions on the interpretations of important doctrines of Tendai Buddhism, Mahāyāna precepts, oral interpretations on each chapter of the Lotus Sütra, collections of oral traditions concerning the the dogmatical interpretations of the Lotus Sütra and Sannō-ichijitsu-shintō (山王一實神道) or Shintoism theoretically based on the Tendai doctrines.

These various works were originally distinct from each other and called the “Kirigami-denju (切紙傳授) or separate-sheet transmission”.

The "separate-sheet transmissions" were classified and compiled in the course of time. They were originally unrelated with each other, so there were no comprehensive system evaluating them. In later days, however, more comprehensive manuscripts of oral transmission appeared and the "separatesheet transmissions" were gradually overlooked. Finally, the manuscript of oral transmission called the “Shichika-kuden (七筒口傳) or Seven Categories” was compiled.

\section{4}

The entire doctrines orally transmitted by the Eshin School can be divided into the Seven Categories consisting of the Four Categories of the Dembō-yoget (傳法要偈) and the Three Categories of the Ryaku-den (略傳). The Four Categories consist of (1) the Triple Introspection of One Mind (一心三觀), (2) the Relation between Subject and Object (心境義), (3) the Key to Calmness and Insight (止觀大旨), and (4) the Deeper Understanding of the Lotus Sutra (法華深義). The Three Categories consist of (5) the Original Triple Body of the Buddha (圓敉三身), (6) the Pure Land of Eternal Tranquility and Light (常寂光土義), and (7) the Causation of the Lotus (蓮華因果). The latter Three Categories are all derived from the forth category of the Deeper Understand-

(2) Saichō, Ennin, and Enchin (圓珍 814-891) are regarded here as the Three Sages; and Annen and Ryōgen as the Two Masters. 
ing of the Lotus Sütra. The Triple Introspection of One Mind is divided into (1) the Triple Aspect of Truth in One Mind as Object (境,一心三諦), and the Triple Introspection of One Mind as Subject (智,一心三觀). The Triple means Void (空), Temporal (假), and Middle (中) aspects of Reality which are also applied to the method of introspection of our minds. Chih-i regards all beings as relative and phenomenal on the one hand; and on the other hand as Void, dependent on others, and having no fixed character in essence. The former aspect is called Temporality whereas the latter Voidness. All beings: are void and at the same time possessed of phenomenal characteristics. Therefore, Voidness and Temporality can be unified into a higher aspect, called Middle, the third aspect, according to the Tendai dialectics. The second category of Relation between Subject and Object means the artless original truth of the Three Thousand Realms in One Notion of Mind ( 一念三千). The third, the Key to Calmness and Insight clarifies both theoretical and practical aspects

(3) This theory is originally found in the Mo-ho-chih-kuan (摩訶止觀 Taisho Tripitaka, Vol. 46, No. 1911.) by Chih-i. The Three Thousand Realms in One Notion of Mind consist of mutually dependent three headings of beings: ten worlds of beings, the ten phases of beings, and the three realms of existence. The ten worlds of being are: hell (naraka), the world of hungry spirits (preta), the world of animals (tiryañc), the world of fighting spirits(asura), the world of human beings(manusya), the world of celestial beings(deva), the world of śävakas, the world of pratyekabuddhas, the world of Bodhisattvas, and the world of Buddhas. The phase of beings are: appearance, nature, substance, power, activity, primary cause, environmental cause, effect, reward and retribution, and the totality of these nine phases. The three realms of existence are sentient beings, non-sentient beings, and the five aggregates consisting of all beings. The authority of this theory in the Mo-ho-chih-kuan runs as follows: "One Mind contains the ten realms of sentient beings. These realms contain one another; therefore, one hundred realms are contained in one mind. Each of these hundred realms, again, contains another set of thirty realms; therefore, in the whole of the hundred realms are contained three thousand realms. These three thousand realms are all contained in one notion of mind. Where there is no mind there is no realm, but where there is mind, however little, none of these three thousand realms is lacking". Cf. Taishō Tripițaka, Vol. 46, p. 54 a. 
of Tendai teaching. The fourth, the Deeper Understanding of the Lotus Sütra consists of the five-fold interpretation of the Lotus Sütra (五重立義) by Chih-i and the Original Enlightenment attained by the Original Buddha Sākyamuni. It is believed that these doctrines were transmitted directly to Chih-i by revelation from the Buddha. Chih-i transmitted them to Kuan-ting (灌頂 561 -632), who transmitted them to Tao-sui. He, in turn, transmitted them to Dengyō Daishi. These doctrines are held to be the important keys to the Lotus Sütra, the Tendai teachings, and to the theory of the attainment to Buddhahood in this mortal body. These are called the Great Matters of the Four Categories (四䇢大事). Dengyō Daishi is said to have transmitted them to Enchō (圓澄 772-837) with his sign of transmission. And in 817, again he is said to have transmitted to Enchō the doctrine of Three Categories of the Original Triple Body of the Buddha, the Pure Land of Eternal Tranquility and Light, and the Causation of the Lotus. The doctrine of Original Triple Body of the Buddha concerns the Eight Stages of the Buddha (證道八相) and the Four Phrases of Enlightenment (四句成道). The Pure Land of Eternal Tranquility and Light is divided into the noumenal and phenomenal aspects. The Causation of the Lotus discusses the relation between the Original Triple Body of the Buddha and the Pure Land of Eternal Tranquility and Light, and finally teaches that we sinful mortals have already attained to Buddhahood. The Lotus here is not meant an analogy, but the very entity of the doctrine.

These Seven Categories are generally called the Great Matters of the

(4) This method of interpretation is given in the Fa-hua-hsüan-i (法華玄義 Taishō Tripițaka, Vol. 33, No. 1716.). Each of the important doctrines is discussed from the five-fold standpoint of name, substance, origin, activity, and doctrine.

(5) They are: descent from heaven, dwelling in mother's womb, being born out of mother, renunciation of the worldy concerns, conquaring the demon, attainment to Buddhahood, turning the wheel of the Law, and entering parinirvāna.

(6) The Four Phrases concern mainly relativity among the original and transformed stages of Bodhisattvahood. But, in some cases, they are applied to the four stages of all the existences: birth, duration, transition, and annihilation. 
Aspects of oral transmission in Japanese Tendai Buddhism(K. Tamura)

Three-fold Seven Categories (三重七箇大事). The three-fold means theoretical (敉), practical (行), and attaining (證). These Seven Categories are to be transmitted at first as theoretical understanding. That is called the theoretical fold. Then, they are to be given from the standpoint of religious practice. That is called the practical fold. And in the end, the final of the practice is dealt with. All the transmissions are to be completed and the certificate of authorized transmission is to be given to each qualified person. In this case, it is called the attaining fold.

The doctrinal contents of the oral transmission of the mediæval age are varied and complicated. They include the important keys of the sect (宗要), the classified items for analysis of the doctrines (義科), and the general items. of catechism (問要). No one knows their exact numbers. But though they are innumerable, each of them is said to be in some way related to one of the Seven Categories. This association is called “narai-awasu(㕷合) or to associate with". Therefore, it is quite natural that, if someone succeeds and understands the Seven Categorical Keys of the doctrines and is given a certificate, he may be said to understand the entire system of oral doctrines.

\section{アメリカ哲學に生きる禪}

アメリカにおいて禪は單に異國的文化としてではなくて，漸くアメリ カ哲學の中心に位置を占めようとしている。最近アメリカの哲學者によ つて禪に關する書が三册刊行された。

Betty and van Meter Ames: Japan and Zen. Published by the University of Cincinnati, Cincinnati, Ohio, 1961.

これはシンシナティ大學の哲學敉授であるエームズ博士の禪に關する 論稿と同夫人の日本印象記をおさめる。

Frederic Spiegelberg: Zen, Rocks, and Waters. Introduction by Sir Herbert Read. Pantheon Books, New York, 1961.

スタンフォード大學敉授シピーゲルバーク博士の一種の禪藝術論であ る。

Abraham Kaplan: The Nere World of Philosophy. Randon House, New York, 1961.

カリフォルニア大學の哲學敎授カプラン博士の世界哲學論であるが， 禪を以て結んである。 （中村 元） 